\title{
Cracking the mirror: on Kierkegaard's concerns about friendship
}

\author{
John Lippitt
}

Received: 19 September 2006 / Accepted: 8 January 2007 / Published online: 13 April 2007

(C) Springer Science+Business Media, Inc. 2007

\begin{abstract}
In this article, I offer a brief account of some of Kierkegaard's key concerns about friendship: its "preferential" nature and its being a form of self-love. Kierkegaard's endorsement of the ancient idea of the friend as "second self" involves a common but misguided assumption: that friendship depends largely upon likeness between friends. This focus obscures a vitally important element, highlighted by the so-called "drawing" view of friendship. Once this is emphasized, we can see a significant aspect - though by no means all - of Kierkegaard's worry as misplaced. However, the "drawing" view also enables us to begin to see what a "Kierkegaardian" friendship might look like.
\end{abstract}

Søren Kierkegaard has often been viewed-wrongly - as an enemy of friendship. In Works of Love, it is alleged, he sets up a stark contrast between the natural loves (erotic love [Elskov] and friendship [Venskab]) on one hand, and love for God and neighbor on the other, ultimately arguing that the former should be replaced by the latter. Numerous critics, such as Theodor Adorno and K. E. Løgstrup, have attacked him on these grounds. Adorno claims that for Kierkegaard, "the differences between individual men ... are, in the Christian sense, of no importance whatever", ${ }^{1}$ and condemns his conception of love as "close ... to callousness". ${ }^{2}$ Løgstrup judges Works of Love to be "a brilliantly thought out system of safeguards against being forced into a close relationship with other people". ${ }^{3}$ Moreover, in three very recent books on the philosophy of friendship, Kierkegaard is still presented as being friendship's unequivocal enemy. Lorraine Smith Pangle, for instance, informs her reader that "Kierkegaard, with bold intransigence, rejects friendship as unchristian". ${ }^{4}$ Sandra

\footnotetext{
1 Adorno (2002, p. 9)

2 Ibid., p. 10

3 Løgstrup (1997). (Løgstrup's book was first published in Danish - as Den Etiske Fordring - in 1956).

4 Pangle (2002).
}

\section{J. Lippitt $(\otimes)$}

Philosophy Department, University of Hertfordshire, de Havilland Campus, Hatfield, Herts AL10 9AB, UK

e-mail: j.a.lippitt@herts.ac.uk 
Lynch repeats the charge that "Kierkegaard opposes friendship ... to 'love of neighbor", 5 and claims that he "dismiss[es] friendship and [erotic] love altogether, as essentially forms of idolatry or self-love". ${ }^{6}$ Mark Vernon is more polemical: he dismisses Kierkegaard's analysis as "one man's rant," again claiming that Kierkegaard's is "an outright rejection of friendship as such" and that for him "neighbor-love is wholly different from friendship." (He also reminds us that Kierkegaard's name means "graveyard", so that he can joke: "True to his name, Mr Kierkegaard does his best to bury friendship". ${ }^{8}$ ) All three critics, in other words, make similar charges against Kierkegaard as did his critics of more than half a century ago, Adorno and Løgstrup. Kierkegaard is still commonly presented as holding either or both of the following views. First, since erotic love and friendship are "preferential", rather than universal, they fail the test of love of the neighbor and should therefore ultimately be dismissed. Second, since one's beloved or closest friend is simply one neighbor amongst many, one's love for one's partner or friend is ultimately no different from one's love for the stranger. In other words, he has no room for "preferential" love at all.

Now, Kierkegaard does indeed claim that "the praise of erotic love and friendship belong to paganism" (WL, p. 44), ${ }^{9}$ and that "Christianity has thrust erotic love and friendship from the throne" (ibid.). Yet he also describes erotic love as "undeniably life's most beautiful happiness" and friendship as "the greatest temporal good" (WL, p. 267). So what is his position; what are Kierkegaard's concerns about friendship? To what extent are they warranted? And if there is merit to them, what form would friendship need to take in order to avoid these worries?

In this article, I shall offer a brief account of some of Kierkegaard's chief concerns about friendship. Drawing on M. Jamie Ferreira's discussion in Love's Grateful Striving, her excellent commentary on Works of Love ${ }^{10} \mathrm{I}$ shall show how much they are dependent upon the idea that friendship is a form of self-love. For reasons that will become obvious, this will highlight the need to consider what might be meant by the ancient idea upon which Kierkegaard trades, that the friend is a "second self". I shall argue that Kierkegaard is not just an unequivocal enemy of friendship. However, I shall also make a qualified criticism of Kierkegaard, namely that an important part of his worry rests on an assumption he shares with numerous other writers: that friendship depends, to a significant degree, upon likeness between the friends. I'll go on to argue that this focus on likeness has obscured a vitally important element of friendship. This element, which following Dean Cocking and Jeannette Kennett ${ }^{11}$ I shall call the "drawing" view of friendship, needs to be re-emphasized. Once the "drawing"

\footnotetext{
5 Lynch (2005, p. 35).

6 Lynch, p. 181.

7 Vernon (2005, pp. 77-78). from the most recent English translation), 17 pages of a 386 page book.

9 Kierkegaard (1995). References to WL will appear in the main text.

10 Ferreira (2001).

11 Cocking and Kennett (1998).

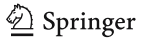

8 Vernon, p. 78. As general studies of the philosophical literature on friendship, both Lynch's and Vernon's books have much to commend them. But on Kierkegaard, they have in common a surprising feature: the exclusion from the bibliography of the very text on which they base their attack on Kierkegaard, Works of Love. Revealingly, what both cite is the small sub-section of Works of Love excerpted in Michael Pakaluk's anthology Other Selves: Philosophers on Friendship (Indianapolis: Hackett, 1991). This sub-section - amounting to twelve pages in Pakaluk's book - is just one third of one of the fifteen deliberations that make up Works of Love. Or, to put it another way (using figures 
view is on the table, I shall argue, we can see that a significant element - though by no means all-of Kierkegaard's worry about friendship is misplaced. But the "drawing" view can also help us begin to see what a "Kierkegaardian" friendship - a kind of friendship of which Kierkegaard could approve-might look like. ${ }^{12}$

\section{Friendship as preferential}

What, then, are Kierkegaard's worries about friendship? First and foremost, that friendship (along with erotic love) is "preferential". As Ferreira notes, Kierkegaard's is an agapeistic ethic, concerned with "commanded love rather than preferential inclination". ${ }^{13}$ In Works of Love, he repeatedly contrasts the Christian worldview with that of "the poet", a figure who eulogizes erotic love and friendship: "The poet and Christianity are diametrically opposite in their explanations. The poet idolizes inclination ...; Christianity ... dethrones inclination and sets this shall [i.e. the commanded nature of neighbor-love] in its place" (WL, p. 50). Kierkegaard illuminates the second love commandment - "You shall love your neighbor as yourself" 14 - by focusing on preference and equality. Neighbor-love is "the opposite of preference": whereas the concepts of the friend and the romantic beloved, by their very nature, distinguish my friend or beloved from those who are not my friend or beloved, nobody - neither stranger nor enemy - is to be excluded from the category of the neighbor; "the neighbor ... is all people" (WL, p. 52). This connects with equality as follows. When Kierkegaard says that the neighbor is one who is equal before God (WL, p. 60), the most important contrast is not between the self and the other, since key to friendship or erotic love at their best is, at the very least, an equal concern for the friend or beloved as well as oneself. Rather, the contrast is between different "others". Neighbor-love insists that I do not exclude any particular other from the scope of my love and care simply on the grounds that he or she is not (unlike my beloved and friends) one to whom I feel preferentially inclined. Thus, as Ferreira notes, "the most crucial distinction Kierkegaard makes is between non-preferential love (Kjerlighed) and preferential love (Forkjerlighed) ... between caring that is not restricted in focus and caring that is restricted" 15 and he is keen that preferential love "should not be the determinant of responsibility for the other". ${ }^{16}$

So far, so good. But Kierkegaard connects this distinction between preferential and non-preferential love with a more contentious set of claims. Only the neighbor, we are told, is truly "what thinkers call "the other" (WL, p. 21). Why not the friend or beloved? Well, the word neighbor [Naste] is "obviously derived from 'nearest' [Narmeste]; thus the neighbor is the person who is nearer to you than anyone else, yet not in the sense of preferential love, since to love someone who in the sense of

12 Although as noted Kierkegaard's position has often been understood as being an unequivocal rejection of the value of friendship, he explicitly distances himself from this position: "If in order to love the neighbor you would have to begin by giving up loving those for whom you have preference, the word 'neighbor' would be the greatest deception ever contrived" (WL, p. 61). The idea is rather that we should "in erotic love and friendship, preserve love for the neighbor" (WL, p. 62, my emphasis). We shall return to this, in order to begin to unpack what this claim amounts to, in section 4 .

13 Ferreira, p. 40.

14 See Matthew 22: 39; Mark 12: 31; Luke 10: 25-37.

15 Ferreira, p. 43.

16 Ibid., p. 46. 
preferential love is nearer than anyone else is self-love" (WL, p. 21, my emphasis). We shall need to look at this claim - that preferential love is a form of, perhaps disguised, self-love-in detail, since it is central to his argument. ${ }^{17}$ Ferreira glosses the basic idea as follows. We need the category of the neighbor, according to Kierkegaard, "to safeguard the alterity of the other, to be sure that in love we allow the other to be more than an extension of ourself'. ${ }^{18}$ The claim is that friendship (and erotic love), insofar as they are preferential, are not up to this task. Why does Kierkegaard claim this? And is he right to do so?

There are two claims here which, though connected by Kierkegaard, should perhaps be kept apart. The first - that friendship is preferential and that neighbor-love introduces an impartiality that friendship lacks - seems uncontroversial enough. (To say this, though, is not to deny the possibility that we might have particular duties to those we love in the preferential sense that we do not have to strangers.) But my focus here is on the second claim, which should be broken down into two constituent parts: first (claim A), that preferential love-and therefore friendship-is a form of self-love; and second (claim B), that in friendship the other is simply an extension of oneself. In what follows, I shall argue that Kierkegaard is wrong to infer claim B from claim A. In other words, even if he is right that friendship is a form of self-love, this is so in an innocuous sense, such that the worry he builds upon it - that such friendship therefore treats the other as simply an extension of oneself-does not follow. Indeed, as noted at the outset, by investigating this point, and the "drawing" view of friendship, we can get closer to seeing what a form of friendship of which Kierkegaard could approve would look like.

\section{Friendship as self-love}

We need to approach this in stages. First, we need to consider the phenomenon of self-love. Even if it were true that friendship was a form of self-love, this would only be objectionable if self-love per se were objectionable. But is it? According to Kierkegaard, the answer is 'No'. As Ferreira emphasizes, Works of Love draws upon a distinction between selfish and legitimate forms of self-love, ${ }^{19}$ and what Kierkegaard is opposing is the former, not the latter. He notes that the second love commandment, with its "as yourself", itself presupposes "that every person loves himself" (WL, p.17). Properly understood, he insists, the commandment insists on loving oneself "in the right way" (WL, p. 22). A distinction needs to be made, therefore, between "proper self-love" (WL, p. 18) - which Kierkegaard endorses, and argues that Christianity endorses - and "selfish self-love" (WL, p. 151), and it is only the latter that should be condemned. (Indeed, he even insists that loving oneself in the right way and loving the neighbor "fundamentally ... are one and the same thing" (WL, p. 22).) According to Ferreira, the essence of this distinction between selfish and proper self-love is to be found in the kind of love of self that is "at odds with the good of the other", and that

\footnotetext{
17 Note in passing that Kierkegaard claims it is a mistake to see Christianity as being opposed to erotic love because of its fleshly sensuousness: "By the sensuous, the flesh, Christianity understands selfishness ... self-love is sensuousness. Christianity has misgivings about erotic love and friendship simply because preferential love in passion or passionate preference is actually another form of self-love" (WL, pp. 52-3, my emphases).

18 Ferreira, p. 43, my emphasis.

19 Ibid., pp. 31-32.

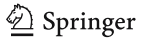


"which both encompasses the good of the other and is the measure of the good of the other". 20

But if there is such a thing as "proper self-love" then what matters is not merely whether friendship is a manifestation of self-love, but whether it is a manifestation of illegitimate, or selfish, self-love. And as we shall see, in his comments on friendship, Kierkegaard is sometimes less careful than he should be about respecting this distinction.

How does Kierkegaard argue for the claim that "passionate preferential love" (WL, p. 53) is a form of self-love? A key part of the argument seems to be to do with exclusivity:

Just as self-love selfishly embraces this one and only self that makes it selflove, so also erotic love's passionate preference selfishly encircles this one and only beloved, and friendship's passionate preference encircles this one and only friend. For this reason the beloved and the friend are called, remarkably and profoundly, to be sure, the other self, the other I-since the neighbor is the other you, or quite precisely, the third party of equality. The other self, the other I. But where does self-love reside? It resides in the $I$, in the self. Would not self-love then also start loving the other I, the other self? One really does not need to be any great judge of human nature in order with the help of this clue to make discoveries about erotic love and friendship that are alarming to others and humiliating to oneself. The fire that is in self-love is spontaneous combustion; the $I$ ignites itself by itself. But in erotic love and friendship, in the poetic sense, there is also spontaneous combustion. (WL, pp. 53-4)

The central claim, then, seem to be something like this. Love of my beloved and my friend, like love of myself, excludes love for all those others who are not my beloved or friend. This is a trap into which love of the neighbor-who is everyone-does not fall. Moreover, the beloved and friend are called ("profoundly", and therefore, presumably, truthfully) the "other self". The idea here, in regard to friendship, seems to be that I see in my friend some reflection of myself, such that love for my friend is a kind of disguised love for myself. Furthermore, the reference to the neighbor as the "first you", according to Ferreira, signals the need to relate to the other "as a genuine other", ${ }^{21}$ not just as some sort of reflection of myself, "another me". ${ }^{22}$ Only the neighbor, then, is "what thinkers call 'the other', that by which the selfishness in self-love is to be tested". ${ }^{23}$ Selfish self-love is where the other is seen simply as an extension of the self; in which the other's alterity is not respected. Proper self-love is where this alterity is respected. In a nutshell, then, Kierkegaard's real objection is to the way in which we often turn the other into "another me".

All this raises at least two questions. First, the basis for the exclusivity charge in the case of myself is pretty obvious. Likewise in the case of "erotic love", to anyone familiar with the myths of romantic love, according to which there is one person for each of us; our "soul mate". (Versions of this myth are, of course, found in sources as diverse as Aristophanes' speech in Plato's Symposium and excited chatter at the

20 Ibid., p. 35.

21 Ibid., p. 52.

22 Ibid., p. 8.

23 Ibid., p. 21. 
water cooler about how last night's date might finally be "the one".) But we might well wonder why Kierkegaard lumps erotic love and friendship together here, since this idea of exclusivity seems to jar with our ordinary understanding of friendship. Certainly, not everyone could be my friend, but I can surely have more than one of them. We need to clarify, therefore, why the claim of exclusivity is made in the case of friendship ("this one and only friend").

Second, exactly what is meant by the idea that the friend is the "other self"? We shall need to investigate the origin and possible meanings of this phrase, which will enable us to consider whether the apparent meaning Kierkegaard attributes to it - which is what enables him to make the "selfishness" charge-is warranted.

Let us address each of these points in turn. First, why talk of friendship in terms of exclusivity?

\subsection{Friendship and exclusivity}

Kierkegaard's reasons for doing so become less surprising the more we examine the philosophical literature on friendship. Quite prevalent in that literature is what Sandra Lynch describes as a "highly idealised" 24 view of what friendship involves. Lynch notes that some of the most influential views in the philosophy of friendship, which tend to focus on relationships between virtuous men, view friendship at its best as being characterized by "complete union of feeling on all subjects". ${ }^{25}$ For Cicero, for example, man "is ever on the search for that companion, whose heart's blood he may so mingle with his own that they become virtually one person instead of two". ${ }^{26} \mathrm{He}$ defines friendship as "complete sympathy in all matters of importance, plus goodwill and affection". ${ }^{27}$ Clearly, the number of people with whom this is possible will be small. The apotheosis of this view, however, comes in Montaigne, in his eulogy for his friendship with Etienne de la Boétie. In such a friendship - which, Montaigne claims, was "so entire and so perfect that ... it is a lot if fortune can do it once in three centuries" 28 - the two friends share a perfect harmony in world-view: "our souls mingle and blend with each other so completely that they efface the seam that joined them, and cannot find it again". ${ }^{29}$ Of la Boétie's death, he writes: "I was already so formed and accustomed to being a second self everywhere that only half of me seems alive now". ${ }^{30}$ Against this background, it becomes easier to see why Kierkegaard conjoins the friend with the lover: for instance, why he talks about "when the lover or friend is able to love only this one single person in the whole world" (WL, p. 55, my emphasis). Passages such as these from Montaigne also make it easier to see why Kierkegaard would make the following charge:

erotic love and friendship are the very peak of self-esteem, the $I$ intoxicated in the other $I$. The more securely one Iand another $I$ join to become one $I$, the more this united $I$ selfishly cuts itself off from everyone else. At the peak of

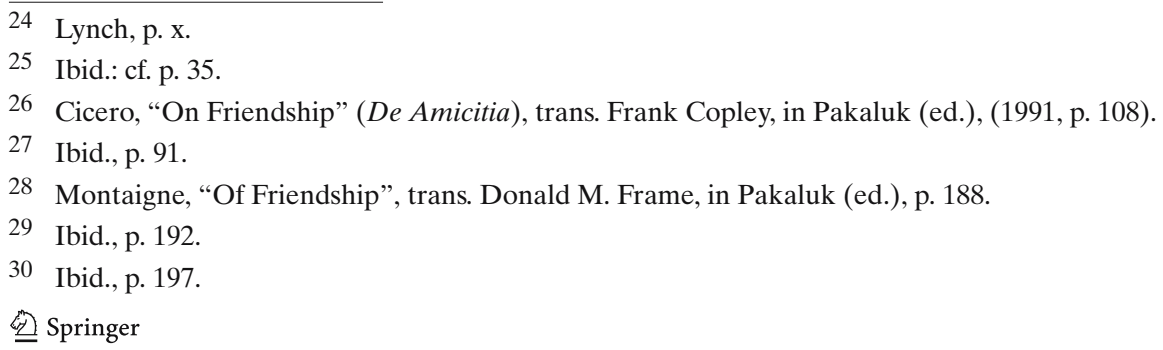


erotic love and friendship, the two actually do become one self, one $I$. (WL, p. 56)

Similarly, C. S. Lewis claims that "every real friendship is a sort of secession, even a rebellion". ${ }^{31}$ How so? Since friendship is by its very nature preferential, what Lewis is worried about - what he calls the "pride" of friendship -involves cliquishness: the friends setting themselves up as an "us" defined in opposition to a "them". This has subtle and not so subtle manifestations, but at its worst everyone "who is not in the circle must be shown that he is not in it. Indeed the Friendship may be 'about' almost nothing except the fact that it excludes". ${ }^{32}$ What Lewis shows - more clearly, perhaps, than does Kierkegaard-is the danger of this particular slippery slope: "From the innocent and necessary act of excluding to the spirit of exclusiveness is an easy step; and thence to the degrading pleasure of exclusiveness". ${ }^{33}$ At the bottom of this slope, "[t]he common vision which first brought us together may fade quite away. We shall be a coterie that exists for the sake of being a coterie; a little self-elected (and therefore absurd) aristocracy, basking in the moonshine of our collective self-approval". ${ }^{34}$ And when friendship takes this form, a close relation of the kind of mutual intoxication we saw Kierkegaard describe above, the threat to non-preferential love of the neighbor is obvious. But the obvious objection is that friendship does not have to fall into the trap of mutual intoxication more commonly associated with a certain kind of romantic love. We shall briefly return to this in Sect. 4.3

\subsection{The friend as "second self"}

Let us turn to the second issue, the idea of the friend as a "second" or "other" self. Kierkegaard anticipates the objection that since for "the poet" erotic love and friendship inhere in (selfless?) devotion to the beloved or true friend, the charge of self-love must be misplaced. "But how can devotion and unlimited giving of oneself be selflove?" he asks on the poet's behalf. His answer: "when it is devotion to the other I, the other self" (WL, p. 54). As noted, then his view seems to be that erotic love and friendship are forms of self-love insofar as the friend is an extension of the self. But in what sense?

Several philosophers - most famously Aristotle, but also Cicero, Thomas Aquinas and Montaigne, amongst others - describe the friend as a second or other self. (Indeed, though Aristotle is typically credited as the original source of this phrase, it has been suggested that it may go back as far as Pythagoras. ${ }^{35}$ ) But there is little doubt that the most famous description of the friend as a "second self" is that in Aristotle's Nicomachean Ethics. ${ }^{36}$ It is important to note that Aristotle's discussion is closely linked to his treatment of friendship as being rooted in likeness or similarity. In this context, I shall consider the charge (made recently by Lynch) that many philosophical accounts of friendship (including Aristotle's) place an excessive focus on similarities rather than differences between friends. Not enough has been said about what a focus on differences would add. We can begin to fill this lacuna by arguing for the importance

31 Lewis (1960).

32 Ibid., p. 85.

33 Ibid., p. 86.

34 Ibid.

35 See White (1992, p. 19).

36 All quotations are from the following edition: Aristotle (1998). 
of supplementing the so-called "mirror" view of friendship derived from Aristotle with the "drawing" view argued for recently by Cocking and Kennett.

Although near the start of his discussion Aristotle mentions the idea of opposites attracting, shortly afterwards he asserts that "every friendship ... is in accordance with some likeness" 37 and later repeats that "like is friend to like". ${ }^{38}$ Perfect or complete friendship - as opposed to his two lower varieties of friendship, those of pleasure and utility-occurs between "good people alike in virtue". ${ }^{39}$ Moreover, Aristotle claims that in relationships between lovers, it is likeness in character that is most likely to sustain a relationship once "youth fades". ${ }^{40} \mathrm{He}$ does recognize the possibility of friendships between unequals, but overall concludes that "equality - and likeness - is friendship, and especially the likeness of those alike in virtue". ${ }^{41}$ Friendship between men with contrary needs, such as the rich and poor, is treated as mere utility friendship. ${ }^{42}$ Aristotle's predominant focus in discussing friendships between unequals and those that are not alike is on problems that are likely to arise from these dissimilarities. And of people unalike in virtue, he asks:

How could they be friends if they neither approved of the same things nor enjoyed and disliked the same things? For not even with regard to each other will these pertain, but without this ... they cannot be friends, since they are incapable of sharing in a way of life. ${ }^{43}$

Ceteris paribus, the picture seems to be that the more alike two people are, the better are their chances of a lasting friendship. ${ }^{44}$ Kierkegaard seems to buy into this general idea. He claims that:

In erotic love and friendship, the two love each other by virtue of the dissimilarity or by virtue of the similarity that is based on dissimilarity (as when two friends love each other by virtue of similar customs, characters, occupations, education, etc., that is, on the basis of the similarity by which they are different from other people, or in which they are like each other as different from other people). Therefore the two can become one self in a selfish sense. (WL, p. 56)

But is this necessarily true? Noting the prevalence in the philosophy of friendship to emphasize "shared concerns, shared character traits, even complete fusion on all matters" Lynch argues that such conceptions of friendship fail precisely to take sufficient account of the "otherness" of the friend. She claims that "the friend in traditional concepts of friendship becomes an impossible idea-a reflection of oneself and perhaps

37 Ibid., 1156b.

38 Ibid., 1165 b.

39 Ibid., 1156b.

40 Ibid., 1157a.

41 Ibid., 1159b.

42 Ibid., 1159b. In such a case, if I am richer than you, but you are especially witty and good fun to be with, you may find my friendship useful (insofar as I bestow some of my wealth on you), but I gain too, insofar as I gain pleasure from your amusing company. See 1158a.

43 Ibid., 1165 b.

44 Cicero expresses similar ideas. He talks of sharing "the one element indispensable to friendship, a complete agreement in aims, ambitions and attitudes"; claims that "the man who keeps his eye on a true friend, keeps it, so to speak, on a model of himself"; and adds that "there is nothing that so attracts and draws anything to itself as likeness of character does friendship" (Cicero, ibid., pp. 85, 88, 98, my emphases). 
even of one's own narcissism - but never a challenge or threat; that is, never a genuine other". 45

Aristotle's focus on similarity makes it natural for him to introduce his much celebrated metaphor of the friend as a mirror of the self. Perhaps the clearest expression of this is in the Magna Moralia, where we are told:

we are not able to see what we are from ourselves ... as then when we wish to see our own face, we do so by looking into the mirror, in the same way when we wish to know ourselves we can obtain that knowledge by looking at our friend. For the friend is, as we assert, a second self. If, then, it is pleasant to know oneself, and it is not possible to know this without having some one else for a friend, the self-sufficing man will require friendship in order to know himself. ${ }^{46}$

The overall idea is that I can see myself in the mirror of my friend only because my friend is in the critical respects like me.

Is Aristotle guilty of Lynch's charge of placing an excessive focus on similarity? Here Aristotle commentators disagree, not least because they disagree on exactly which aspect of the ambiguous phrase "another self" should be emphasized. Pangle puts the issue thus:

As another self, is the friend loved mainly as a reflection or extension of oneself, or as a separate being with different qualities? Again, as another self, is he loved as belonging to oneself, or as a true, independent end ${ }^{47}$

I shall not attempt to resolve this aspect of Aristotle interpretation here. But to see more clearly the problem at issue here for the present article's purposes, consider an important section of Works of Love, the deliberation "Our duty to love the people we see". There, Kierkegaard insists on the duty to love people "as they are" (WL, p. 166); "to love precisely the person one sees" (WL, p. 173). What is at stake here is as follows:

in loving the actual individual person it is important that one does not substitute an imaginary idea of how we think or could wish that this person should be. The one who does this does not love the person he sees but again something unseen, his own idea or something similar. (WL, p. 164)

One obvious instance of this is romantic infatuation, neatly described by John Armstrong as "using another person as a prop in a fantasy about ourselves". ${ }^{48}$ But there are manifestations of this in friendship too: not only when we reduce the friend to someone who is useful to us in some way, but also when we see or focus on only what we have in common with the friend, those aspects of ourselves that they "reflect". The mirror can be a symbol of narcissism as much as of self-revelation. In all such cases, the worry is that what we are loving is what Ferreira calls "the self-generated image of the other person", which is "not the same as loving the actual other person at all". 49 In other words, we fail to relate to the friend as a genuine other. We overlook the idea that the other cannot legitimately be reduced to our preconceived idea of them.

\footnotetext{
45 Lynch, p. 82.
}

46 Aristotle (1984), 1213a. Some Aristotle scholars claim that this text is probably not genuinely by Aristotle. But insofar as, in the present respect, the text encapsulates an idea to be found in texts of less dubious authenticity, it does not seem unreasonable to utilise it here.

47 Pangle, p. 152.

48 Armstrong (2002, p. 79).

49 Ferreira, p. 109. 


\section{Cracking the mirror: the "drawing" view of friendship}

To avoid this potential problem, I suggest that what Cocking and Kennett call the "mirror" view of friendship derived from Aristotle needs to be complemented by what they call the "drawing" view. The "drawing" view, I claim, shows something about why a friendship in which there are important differences between friends can have a value that friendships of perfect unity, harmony and likeness would lack. A. W. Price suggests: "A potential aspect of my personality may respond to an aspect of yours not by mimicking it, but by complementing it. Lives are shared through exchanging as well as embracing thoughts". ${ }^{50}$ The "drawing" view puts some useful flesh on the bones of this intuition. And, as mentioned earlier, it goes some way towards dispelling Kierkegaard's concern that friendship might involve a form of illegitimate self-love.

Cocking and Kennett criticize both the "mirror" view of friendship (in which what marks companion friendship is the great extent to which we see ourselves in the friend) and what they call the "secrets" view (in which companion friendship is marked by the extent to which we are prepared to disclose ourselves to our close friends). For their "drawing" view, characteristic of being a close friend of another is being "receptive to being directed and interpreted and so in these ways drawn by the other". 51 Their claim is that people can be companion friends "precisely with respect to the ways in which they are dissimilar", 52 such as where each provides a useful corrective to the other. Consider the example of:

two friends, one of whom is deeply cautious and the other rather reckless. These friends recognize the contrast between their characters, and this contrast plays a significant role in structuring their relationship. The cautious one knows that she could never resemble her friend in recklessness, yet she is attracted by this aspect of his character. The reckless one, while remaining quite reckless, regards with affection his friend's caution. Far from being extrinsic to the friendship these dissimilar features are features in respect of which they are friends and which govern much of the interplay between them. ${ }^{53}$

For Cocking and Kennett, the really significant feature of companion friendship is not similarity of interests, but being "responsive to our interests being directed by each other". 54

To illustrate what they mean by "responsiveness" and "direction", consider another example:

my friend Iris asks me to the ballet and on account of this interest in the ballet being Iris's interest I willingly accept this invitation. I may never have had any real interest in ballet yet I do not go begrudgingly or out of any sense of obligation. Rather I am happy to be moved directly by her interest in choosing to spend the evening this way; I am happy to attend the ballet with her when I would certainly not be interested, or in this way interested, if I was asked by someone else, say, for example, a new colleague or my elderly aunt. ${ }^{55}$

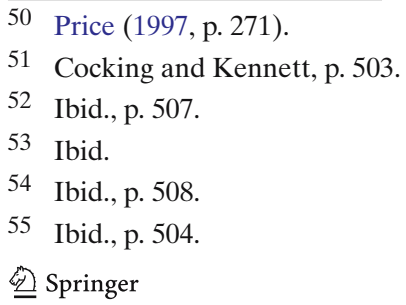


Of course, there could be other reasons to accept the invitation from someone other than a friend. As they allow, if I don't know many people at work, the colleague's offer might be tempting as a way of getting to know him better; or I may feel a sense of duty to my aunt, who loves ballet but doesn't get out much. However, Cocking and Kennett's point is that in these latter cases, my motivation is something other than the fact that the ballet is the other's interest. In other words, the claim is that characteristic of close friendship is a willingness to accept such an invitation because it is the friend's interest: "one can be disposed to be interested in pursuing certain activities that one otherwise would not be, simply on account of one's friend". 56

Proponents of the "mirror" or "similarity" view might respond to this by pointing out that, in such a case, I might develop an interest that I never previously had: having gone along just because of Iris, I might find that I really enjoy the ballet, such that it starts to become a genuine interest of mine too. In this sense, then, I will become more like Iris: our similarity will increase. But while this is of course possible, Cocking and Kennett rightly claim that it isn't the possibility of increased similarity that matters. It is just as likely that my latent interest in the ballet might not take off. If Iris never asks me again, I may do nothing to seek out the ballet for myself, and yet have no regrets about having shared her interest for an evening or two. If this is right, then what matters is not similarity - actual or potential - but "the distinctive kind of responsiveness to the other". 57

A second key feature of Cocking and Kennett's view of friendship is how we come to see ourselves through our friends' eyes. In another of their examples, if Judy "teasingly points out to John how he always likes to be right" John might come to recognize and accept this as a feature of his character: "seeing himself through Judy's eyes changes his view of himself". 58 But suppose that, as well as the bare recognition of this, the close friend's interpretation of one's traits or foibles impacts on how that trait manifests itself:

Within the friendship John's liking to be right may become a running joke which structures how the friends relate to each other. John continues to insist that he is right; however, his insistences are now for the most part treated lightheartedly and take on a self-consciously ironic tone. And John may be led by Judy's recognition and interpretation of his foibles to more generally take himself less seriously. Thus John's character and self-conception are also, in part, drawn, or shaped by his friend's interpretations of him. ${ }^{59}$

Cocking and Kennett claim that having “one's interests and attitudes directed, interpreted, and so drawn ... is ... both typical and distinctive of companion friendships, yet has been largely neglected in philosophical literature on the subject". 60 This addresses a key feature of friendship that the "secrets" and "mirror" views do not:

It is not that I must reveal myself to, or see myself in, the other, to any great extent, but that, in friendship, I am distinctively receptive both to the other's interests and to their way of seeing me. ${ }^{61}$
56 Ibid.
57 Ibid.
58 Ibid., p. 505.
59 Ibid., my emphasis.
60 Ibid.
61 Ibid. 
Noticing this has several advantages. One advantage of the "drawing" view is that it places centre-stage the fact that friendship is relational in a way that the "mirror" view does not. Second, and relatedly, I mentioned earlier that Aristotle discusses those with contrary needs, such as a friendship between a poor man whose wit endears him to a rich man from whom he hopes to gain financially (that is, a relationship in which pleasure and utility are traded). But some relation of contrary need is present in pretty much any friendship. What the "drawing" view underlines is that even amongst those Aristotle would class as the virtuous, people's characters develop in part by the ways in which they are drawn to, and by, their friends. In other words, this is an entirely natural part of more than just friendships of utility or pleasure. Third, at the end of his discussion of friendship in the Nicomachean Ethics, Aristotle discusses the importance of mutual influence within friendship. "For each class of persons, whatever existing is for them - that for the sake of which they choose to live - is what they wish to engage in with their friends". ${ }^{62}$ Each group of people spends their time on "whatever thing in life they are the most fond of". ${ }^{63}$ Thus the bad influence each other for ill and the good influence each other for good, "since they copy each other in what they find pleasing". ${ }^{64}$ But only in a very minimal sense does such mutual positive influence depend upon likeness. Although two such friends must be, in some sense, "good", nothing prevents their being good in radically different ways. For this reason, talk of "likeness" in virtue can be misleading. Why should we place all the emphasis on the friend's similarity? In an influential discussion of Aristotle on friendship, John Cooper reads the mirror image as follows: "even an intimate friend remains distinct enough to be studied objectively; yet because one intuitively knows oneself to be fundamentally the same in character as he is, one obtains through him an objective view of oneself". ${ }^{5}$ But why not, following Cocking and Kennett, suggest that it is "at least as plausible to suppose that one might gain self-awareness from the friend's objective presentation of dissimilarity to oneself" 66 ? To use the earlier example, it is by your friend's presentation of what it is to be cautious that you see how reckless you are. In other words, your friends may well enhance your self-awareness and self-understanding, but there is no reason to suppose they necessarily do this in virtue of their likeness to you.

I am suggesting, then, that Cocking and Kennett are right that having one's interests and attitudes "directed, interpreted, and so drawn" is a feature of friendship that has been largely overlooked in the philosophical literature on that topic. So how does this address Kierkegaard's concern? We have noted that a key part of Kierkegaard's worry about friendship qua preferential love is that it is typically a form of illegitimate self-love: thinking of the friend as a "second self" threatens to fail to respect the friend's genuine otherness. This does seem to be a danger faced by the "mirror" view, and any account of friendship that places the primary emphasis on the way in which my friend is "like me". But Kierkegaard expresses this view of friendship in large part because of his tacit assumption that I prefer my friends in virtue of their likeness to me. Whereas if the "drawing" view is on the mark, then Kierkegaard's conclusion is too hasty. I have argued that the "mirror" or "likeness" view tells only part of the story. The "drawing" view - which focuses not just on ways in which we are different

\footnotetext{
62 Aristotle, Nicomachean Ethics, 1172a.

63 Ibid.

64 Ibid.

65 Cooper (1980, p. 322).

66 Cocking and Kennett, p. 512.

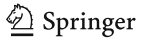


from our friends, but on ways in which we are drawn to and by, and in some cases changed by, the friend precisely through the ways in which we differ-does not face the danger in question.

\section{Neighbor-love in friendship}

By way of spelling out in more detail what the "drawing" view brings to the table, I want, in this final main section, to do three things. First, to suggest that just as we can "work outwards" from our natural love of ourselves, so we can work outwards from friendship, to love of the neighbor. This is perhaps not something Kierkegaard would deny, but neither is it something he emphasizes. The second and third points are related. One of Kierkegaard's central claims is not-pace Lynch-that preferential love needs to be eliminated, but that the selfishness in preferential love needs to be eliminated. ${ }^{67}$ Yet as we have seen, Kierkegaard tends to paint a rather unflattering portrait of friendship when it is not infused with neighbor-love. I will suggest - the second point - that some of the distinctions Kierkegaard draws between neighborlove and such friendship are unfair, since the best forms of "pagan" friendship are much less graspingly self-serving than Kierkegaard's picture implies. And yet - the third point-since I do recognize the importance of neighbor-love, I shall close by considering some important features friendship would need to have (or avoid) in order to be the kind of friendship of which Kierkegaard could approve. We shall see that several of these are features of friendship emphasized by the "drawing" view.

\subsection{From friendship to neighbor-love?}

One important implication of our discussion so far is that all genuine love should be love of a distinct individual. ${ }^{68}$ Kierkegaard's emphasis on the neighbor as the "first you", a "genuine other", nicely brings out the important difference between loving someone as a particular individual and loving someone as an instantiation of some property. This is important because our talk of love of the neighbor all too easily fails to respect this division: "the neighbor", far from being this particular person here, very easily becomes an instantiation of the general category "neighbor". There is a crucial difference between seeing the neighbor as this flesh and blood individual, and seeing them as, say, "he/she who must be helped". But to love at all, Kierkegaard effectively points out, involves seeing the person who is the object of one's love as an irreplaceable individual, and this is just as true when that person is one's neighbor as when he or she is one's romantic beloved or friend. However, here is where friendship qua preferential love has an important role: not just as something that is allowed, but that as something that may well form an important bridge between love of self and love of neighbor. The point is put thus by J. H. Newman:

by trying to love our relations and friends, by submitting to their wishes though contrary to our own, by bearing with their infirmities, by overcoming their occasional waywardness with kindness, by dwelling on their excellences and trying to copy them, thus it is that we form in our hearts that root of charity which,

67 Ferreira, p. 46 and Evans (2004, p.208), both make this point. Lynch claims that Kierkegaard's view is that "Since friendship is preferential, it is by definition selfish" (Lynch, p. 35).

68 Furtak (2005, p. 103) points out that this is Kierkegaard's major criticism of Plato's idea of love. 
though small at first, may, like the mustard seed, at last even over-shadow the earth. ${ }^{69}$

Part of the idea here seems to be that it is easier to see the friend as an individual than it is the neighbor, perhaps given the potential of the latter all too easily to become an abstract category. And on the "drawing" view, the reason this is so is because of those aspects which she distinctly, and perhaps uniquely, draws out of us. ${ }^{70}$ But just as we can work outwards from our natural love of ourselves to love of others so, as Newman suggests, we can work outwards from our natural love of our friend to love of the neighbor.

\subsection{Friendship and the "virtues of the pagans"}

In the interests of fairness, we should now consider that the nobler varieties of friendship, even if not infused with Christian neighbor-love, can still reach greater heights than Kierkegaard sometimes allows. To show this in detail is beyond the scope of a single article. But I shall aim to illustrate this general point by briefly considering two important claims Kierkegaard makes about the necessity of neighbor-love: that friendship (qua preferential love) "contains no moral task" and that friendship is a form of being for oneself, which excludes self-denial. At its best, I suggest, "pagan" friendship can easily avoid these charges.

\subsubsection{Friendship as a "moral task"}

One of the ways in which Kierkegaard distinguishes Christianity's view of love from that of "the poet" is as follows:

erotic love and friendship, as the poet understands them, contain no moral task. Erotic love and friendship are good fortune ... It is a stroke of good fortune ... to find this one and only friend. At most then, the task is to be properly grateful for one's good fortune. But the task can never be to be obliged to find the beloved or to find this friend (WL, pp. 50-1).

This seems related to the later claim that "love is qualified as a matter of conscience only when either God or the neighbor is the middle term, that is, not in erotic love and friendship as such" (WL, p. 142, my emphases). Now, the main point of the deliberation from which this second quote comes ("Love is a matter of conscience") is to emphasize that Christianity makes every human relationship a matter of conscience: it emphasizes the obligation to love all, not just those to whom we feel a preferential inclination. Yet Kierkegaard claims that:

Christianity has not changed anything in what people have previously learned about loving the beloved, the friend, etc., has not added a little or subtracted

69 Newman (1868, vol. 2, no. 5, p. 55).

70 Cf. C. S. Lewis: "In each of my friends there is something that only some other friend can fully bring out. By myself I am not large enough to call the whole man into activity; I want other lights than my own to show all his facets" (Lewis, p. 61). But what is true of a given friend is surely also true of oneself: it may take Susie, specifically, to bring out aspects of oneself that Karen cannot (while Karen brings out aspects that Susie cannot). It is for this reason that Lewis suggests that "true Friendship (sic) is the least jealous of loves. Two friends delight to be joined by a third, and three by a fourth, if only the newcomer is qualified to be a real friend" (ibid.). 
something, but it has changed everything, has changed love as a whole ... This it has done by making all love a matter of conscience, which in relation to erotic love and friendship etc. can signify the cooling of passions just as much as it signifies the inwardness of the eternal life (WL, p. 147).

The final point here seems to address the concern that, for "the poet", talking of preferential love in terms of conscience is likely to seem like a "watering down" of the passion that inspires him. But isn't Kierkegaard setting up a false dilemma by presenting an either/or between his imagined poet and Christianity? Why not remember a third contributor to our discussion: the pagan thinker? What of his view of friendship? After all, "what people have previously learned" about friendship has come very largely from that source. ${ }^{71}$ If we do so, I shall argue, we can see that even if "the poet" views friendship as containing "no moral task", and is suspicious of thinking of friendship in terms of conscience, the same is certainly not true of such thinkers.

The danger of thinking of friendship in terms of inclination is that one can very easily give the impression (as Kierkegaard sometimes does) that friendship on its own is fickle, and can be rescued from such fickleness only by a good healthy dose of neighbor-love. But it does not follow from the fact that my relationship with a particular friend is one of preferential inclination that sustaining this relationship contains "no moral task". And even if paganism has "no intimation" of neighbor-love (WL, p. 44), many a "pagan" thinker seems to have recognized this "moral task". Carolinne White points out that a key feature of Pythagoras' influential view of friendship, for instance, was "loyalty in all circumstances". ${ }^{72}$ This is nicely illustrated by the following anecdote:

Lysis and Euryphamos were two Pythagorean friends who happened to meet when Euryphamos came to worship at the temple of Juno and Lysis was just coming out of the temple; Lysis promised to wait outside until his friend had also worshipped the goddess. But when Euryphamos had finished in the temple he was so absorbed in his own thoughts that he forgot that Lysis was waiting for him and he left the temple by a different gate. Lysis, however, a paragon of fidelity, remained waiting for his friend for the rest of the day, that night and most of the following day until Euryphamos was reminded of Lysis and his promise and went back to the temple to release him. ${ }^{73}$

Whatever one makes of this-and it is far from clear that the Lysis of this anecdote would win a rosette in a practical wisdom contest-it seems that the one charge

71 Although there are significant differences between "pagan" and early Christian views of friendship (see Konstan, 1997 ch. 5, esp. p. 165), there is no doubt about the enormous impact of the former on the views of Christian writers in the early centuries of the church. A particularly interesting example is St. Augustine. Scholars typically note the use by early Christian writers on friendship of the phrase "second self": White, for instance, claims that this is as "common in Augustine's writings as it is in Cicero's" (White, p. 194). She also notes Augustine's “continued attachment [after his conversion] to such ideas as unity and shared interests" (p. 189) in his writings on friendship; the fact that-like several others - he continues to use the term amicitia as well as caritas (p. 190); and that he "continued to refer with approval to Cicero's definition of friendship as 'agreement about matters human and divine together with benevolence and affection"' (ibid.). Another significant fourth century Christian, Gregory of Nazianzus (discussed in detail in White, ch. 4), "does not hesitate to express himself in language that echoes the pagan tradition" (Konstan, ibid., p. 165).

72 White, p. 18.

73 Ibid. 
that could not be leveled against him is fickleness! The message is clear: friendship demands loyalty. Similarly, the alleged fickleness of inclination also contrasts with Euripides' idea that "one of the most important criteria of true friendship is that it perseveres in adversity": 74 sometimes, according to other stories of the time, even up to the willingness to sacrifice one's life for one's friend. ${ }^{75}$ Furthermore, the important moral dimension to pagan friendship also comes out in a point discussed by Cicero and Plutarch, amongst others: the problem of how to distinguish a flatterer from a true friend, and the related ideas, taken up by later Christian writers such as St Basil the Great and St Jerome, that flattery destroys friendship and that true friendship thus demands a degree of frankness. ${ }^{76}$

All this shows that even if Christian neighbor-love does introduce as a new idea that we have a duty to love everyone, the idea that outside Christianity friendship contained "no moral task", and was not a matter of conscience, is certainly false. In other words, even if Kierkegaard's poet "belongs to paganism" (WL, p. 44), there is far more to pagan friendship than dreamed of by this poet. We can agree with Ferreira's interpretation that insisting that we should love the beloved or friend qua neighbor is "Kierkegaard's way of reminding us that a man can no more take advantage of his wife [or friend], because she is his wife [or friend], than of another neighbor". ${ }^{77}$ Just as we "cannot make a sex object out of our wife or husband", so we cannot take advantage of our friend's good-will or generosity, since "each remains a neighbor, an equal before God". ${ }^{78}$ However, we can agree without endorsing the idea that this latter is the only good reason one could have for not taking advantage of a friend. What the category of neighbor "makes new" is the extension of the duty to love to everyone, but it certainly does not follow from this that neighbor-love is necessary to make friendship a matter of conscience, or something with a "moral task". If Ferreira is right, therefore, that Kierkegaard's real objection is to "the relationship that does not have conscience at its heart" ${ }^{79}$ then that does not in and of itself rule out the best pagan friendships.

\footnotetext{
74 Ibid., p. 20. become their friend, but they refuse.) sycophancy, flattery...' (Cicero, ibid., p. 111-12).

77 Ferreira, p. 91, my additions in parentheses.

78 Ibid., p. 92.

79 Ibid., p. 93.

丝 Springer
}

75 Consider, for instance, another story of Pythagorean friends, Damon and Phintias, referred to by Cicero, Plutarch, Ambrose and Jerome, amongst others (see White, pp. 18-19; Konstan, pp. 114-15). The gist of this story is that Phintias, wrongly accused of plotting against the tyrant Dionysius, is sentenced to death. Accepting the charge despite his innocence, he asks only for the rest of the day to arrange the affairs of he and his friend Damon (as friends, they held their property in common). Dionysius agrees on condition that Phintias finds someone to stand as surety for his death, and the latter offers Damon, who agrees. Yet rather than abscond, Phintias returns as promised. So impressed is Dionysius by the friends' mutual loyalty, that he releases them both. (He asks that he too might

76 Plutarch's treatise is entitled "How to discriminate a flatterer from a friend". On Plutarch, see Konstan, pp. 98-105; on Plutarch, Basil and Jerome, see White, pp. 39, 74, 81 and 140. Cicero argues that "flattery is far sorrier [than frankness], for by failing to call wrongdoing to account, it lets a friend fall to his ruin ... It is an essential part of true friendship ... to offer and receive admonition; but it must be offered courteously, not peremptorily, and received with forbearance, not with resentment. By the same sign, we must maintain that there is no danger more deadly to friendship than servility, 


\subsubsection{Friendship as "being for oneself"}

Consider, though, the second charge. Ferreira summarizes it as follows:

Having a friend (or lover) is a proper love of self; loving the friend (or lover) as 'another self' is legitimate, an appropriate way of being for oneself; but although it is proper and good, it is still a way of being for oneself and is to be distinguished from neighbor love, which is a way of being for another. ${ }^{80}$

It is this "being for oneself" element, presumably, that leads Kierkegaard to suggest that jealousy is present in friendship (as well as erotic love): "place as a middle term between two friends the neighbor, whom one shall love, and you will immediately see jealousy" (WL, p. 54). Kierkegaard's suggestion that jealousy might always be present in friendship (and erotic love), even when it doesn't "show" itself (ibid.) comes uncomfortably close to arguing, as C. S. Lewis teasingly puts it (in another context), that "the absence of smoke proves that the fire is very carefully hidden". ${ }^{81}$ And it is worth contrasting this claim of Kierkegaard's with Lewis's very different view of friendship as "the least jealous of loves". ${ }^{2}$ However, in light of the "drawing" view, Ferreira's gloss on what Kierkegaard is saying might prompt the following worry. Even on the "drawing" view, which recognizes the friend as a genuine other and appreciates how she helps me "grow", the focus is still on how she helps me grow. In other words, the focus is still on the self: my character; virtues; etc. This may be proper self-love, but it is still proper self-love. One can understand the temptation to claim that neighbor-love is needed as a way of being for another.

But can we really draw the distinction between friendship and neighbor-love in this way? If friendship is still "being for oneself", how does this explain the pagan who is prepared to die for his friend? On Kierkegaard's picture, "Christianity's essential form" is "self-denial" (WL, p. 56), but "wherever the essentially Christian is absent, the intoxication of self-esteem is at its peak" (ibid.): and-remember-"erotic love and friendship are the very peak of self-esteem" (ibid.). How does such a picture explain the possibility of the self-sacrificing pagan friend? He has "no intimation" of neighbor-love, and yet, on the above view, this is precisely what he would need in order for this action to make sense. Moreover, we saw earlier that Kierkegaard argues that neighbor-love anyway contains a proper self-love. But if this is so, what needs to be shown, as before, is that the self-love involved in dying for one's friend is of the "selfish" rather than the "proper" variety. I find it hard to see what convincing reasons Kierkegaard could give to demonstrate this. Ferreira's earlier definition of this distinction-according to which, in selfish self-love, the friend is seen as simply an extension of the self; and in which his alterity is not respected-hardly seems adequately to describe the person who is prepared to die for his friend. In short, it seems that neighbor-love is not absolutely necessary for "being for another". The noblest kind of pagan friendship surely does include "being for another"-perhaps out of gratitude and appreciation for what one's friend has done for you or "drawn" out of you. It is far from obvious that this kind of self-love is either selfish or in any other way "improper".

\footnotetext{
80 Ibid., p. 62.

81 Lewis, p. 60.

82 Lewis, p. 61: see note 70 above.
} 


\subsection{A friendship based on neighbor-love?}

What, then, would a friendship which had neighbor-love at its heart look like? To give a full account of this is beyond the scope of a single article, but we can draw on Works of Love to make a few suggestions. First and foremost, for Kierkegaard, such a friendship would need to have God as "the middle term". Whereas "worldly wisdom" holds love to be a relation between persons, "Christianity teaches that love is a relationship between: a person-God-a person, that is, that God is the middle term" (WL, p. 107).

However, Kierkegaard scholars often fail to note that this view has its precedents in early Christian views of friendship, such as that of Paulinus of Nola, who insists that in a Christian friendship, it is imperative that Christ is honoured above all else, since "a friendship not built on Christ is not founded on a rock" ${ }^{83}$ Similarly, Augustine insists: "no friends are true friends unless you, my God, bind them fast to one another through that love which is sown in our hearts by the Holy Ghost". 84

Ronald Green and Theresa Ellis note that a key aspect of God being the "middle term" in a love-relationship is that it prevents "worshipful idolatry of the beloved". 85 The equivalent to be avoided in friendship, perhaps, would be the kind of mutual intoxication between friends of which Montaigne - a precursor of Kierkegaard's "poet"? seems to have fallen foul.

But there are other ways in which such a friendship needs to avoid being a manifestation of "selfish self-love". To illustrate in more detail what this might mean, we can draw on remarks Kierkegaard makes in one of the most powerful deliberations in Works of Love. Once again, we shall see, the "drawing" view is helpful. In "Love does not seek its own", Kierkegaard describes two characters who he labels "the rigid, the domineering person" (WL, pp. 270-1) and "small-mindedness" (WL, pp. 271-3). These illustrate recognizable human tendencies that, if thought of in relation to friendship, show the dangers of failing to attend to those elements of genuine openness to the friend as other that the drawing view emphasizes:

The rigid, the domineering person lacks flexibility, lacks the pliability to comprehend others; he demands his own from everyone, wants everyone to be transformed into his image, to be trimmed according to his pattern for human beings. Or he does what he regards as a rare degree of love, on a rare occasion he makes an exception. He seeks, so he says, to comprehend a particular human being, that is, in an altogether definite, specific - and arbitrary - way he thinks of something definite about this person and then insists that the other shall fulfil this idea. Whether this is exactly the other person's distinctiveness or not makes no difference, because this is what the domineering person has supposed about him. If the rigid and domineering person cannot ever create, he wants at least to

83 From a letter of Paulinus, cited in White, p. 153.

84 St. Augustine (1961, book IV, Sect. 4, p. 75). One potentially fascinating theme from his Christian predecessors that Kierkegaard does not take up in any detail, however, is the possibility of a "friendship with God". (On this idea in the early Christians, see Konstan, pp. 167-170; on the idea in St. Thomas Aquinas, see Waddell (2002). If, as Ferreira claims, Kierkegaard's view of friendship is "no less positive than that of Aristotle and Aquinas" (p. 46), this absence is surprising, given the centrality to so much of Kierkegaard's work of the idea of a "God-relationship'. But lack of space prevents me from pursuing this issue further here.

85 Green and Ellis (1999, p. 362).

Springer 
transform - that is, he seeks his own so that wherever he points he can say: See, it is my image, it is my idea, it is my will". (WL, p. 270)

In whatever sphere such a person operates, Kierkegaard continues, his nature is "domineeringly refusing to go out of oneself, domineeringly wanting to crush the other person's distinctiveness or torment it to death" (WL, pp. 270-1). Here, painted in primary colours, is a picture of what friendship can decay into if it does not contain a genuine openness to the friend's otherness.

Similarly "smallmindedness":

The small-minded person has clung to a very specific shape and form that he calls his own; he seeks only that, can love only that. If the small-minded person finds this, then he loves. ... This small-minded alliance is then praised as the highest love, as true friendship, as true, loyal, honest harmony. One refuses to understand that the more they hold together in this way, the further they distance themselves from true love ... small-mindedness itself actually imagines that its miserable invention is the truth, so that it is even honest friendship and genuine sympathy to want to muddle and mess everyone into a likeness to oneself. (WL, pp. 272-3)

In short, both these passages powerfully illustrate the dangers inherent of thinking of friendship only in terms of "likeness" - but also, indirectly, the value of a conception of friendship characterized by a genuine openness to having one's interests and attitudes "directed, interpreted, and so drawn" by the friend.

\section{Conclusion}

In this article, I have argued that while Kierkegaard is far from the unequivocal enemy of friendship he is still commonly presented as being, a significant part of his concern about friendship rests upon an excessive worry that it depends upon likeness between the friends. By considering the "drawing" view as an important complement to the "mirror" view of friendship, we not only enrich our understanding of friendship in general, but also get closer to seeing what it might mean to be a "Kierkegaardian" friend. In particular, the "drawing" view's focus on the way in which I am distinctly responsive both to the other's interests and world-view, and to their way of seeing me, shows friendship not just as something a Kierkegaardian should be "allowed". Rather, it is capable of providing an important bridge between love of the self and love of the neighbor.

Acknowledgements I am grateful to audiences at the Universities of Hertfordshire, Warwick and London (Birkbeck College), and at Nazarene Theological Seminary, Kansas City, for comments on earlier versions of this paper. My thanks also to an anonymous reviewer for this journal whose helpful comments enabled me to clarify a couple of issues.

\section{References}

Adorno, T. W. (2002). On Kierkegaard's Doctrine of Love, Studies in Philosophy and Social Science, 8, 413-29 (reprinted in D. W. Conway (Ed.), Søren Kierkegaard: Critical Assessments of Leading Philosophers vol. II. London and New York: Routledge, 2002, 7-21).

Aristotle (1984). Magna Moralia. In J. Barnes (Ed.), The complete works of Aristotle. Princeton: Princeton University Press. 
Aristotle (1998). Nicomachean Ethics. (Books VIII and IX, trans. with a commentary by Michael Pakaluk) Oxford: Clarendon Press.

Armstrong, J. (2002). Conditions of Love: The Philosophy of Intimacy. London: Allen Lane.

Cocking, D. \& Kennett, J. (1998). Friendship and the self. Ethics, 108, 502-527.

Cooper, J. (1980). Aristotle on Friendship. In Amélie Rorty (Ed.), Essays on Aristotle's Ethics. Berkeley: University of California Press.

Evans C. S. (2004). Kierkegaard's Ethic of Love. Oxford: Oxford University Press.

Ferreira, M. J. (2001). Love's Grateful Striving: A Commentary on Kierkegaard's Works of Love. Oxford: Oxford University Press.

Furtak, R. A. (2005). Wisdom in love: Kierkegaard and the ancient quest for emotional integrity. Notre Dame, IN: University of Notre Dame Press.

Green, R. M., \& Ellis, T. M. (1999). Erotic love in the religious existence-sphere. In R. L. Perkins (Ed.), International Kierkegaard commentary: Works of Love. Macon, GA: Mercer University Press.

Kierkegaard, S. (1995). Works of Love (Trans. Howard V. and Edna H. Hong). Princeton: Princeton University Press.

Konstan, D. (1997). Friendship in the Classical World. Cambridge: Cambridge University Press.

Lewis, C. S. (1960). The Four Loves. New York: Harcourt, Brace.

Løgstrup, K. E. (1997). The Ethical Demand (ed. H. Fink \& A. MacIntyre, Trans. Theodor I. Jensen and Gary Puckering). Notre Dame: University of Notre Dame Press.

Lynch, S. (2005). Philosophy and Friendship. Edinburgh: Edinburgh University Press.

Newman, J. H. (1868). Parochial and Plain Sermons. London.

Pakaluk, M. (ed.) (1991). Other Selves: Philosophers on Friendship. Indianapolis: Hackett.

Pangle, L. S. (2002). Aristotle and the Philosophy of Friendship. Cambridge: Cambridge University Press.

Price, A. W. (1997). Afterword, in his Love and Friendship in Plato and Aristotle. Oxford: Clarendon Press.

St. Augustine (1961). Confessions (Trans. R. S. Pine-Coffin) Harmondsworth: Penguin.

Vernon, M. (2005). The Philosophy of Friendship. London: Palgrave.

Waddell, P. J. (2002). Becoming friends: Worship, justice and the practice of Christian Friendship. Grand Rapids, MI: Brazos Press.

White, C. (1992). Christian Friendship in the Fourth Century. Cambridge: Cambridge University Press. 